\title{
Assessment of Natural Radioactivity and Radiation Hazards of Building Materials in Kinondoni District, Dar es Salaam, Tanzania
}

\author{
Huruma P. Mammba ${ }^{1 *}$, Vitus A. Balobegwa ${ }^{1}$, Alex P. Muhulo ${ }^{1}$, Peter A. Pantaleo ${ }^{2}$ and \\ Remigius A. Kawala ${ }^{2}$ \\ ${ }^{1}$ Eastern Zone, Tanzania Atomic Energy Commission (TAEC), P. O. Box 80479, Dar es Salaam, \\ Tanzania \\ ${ }^{2}$ Tanzania Atomic Energy Commission (TAEC) Headquarters, P. O. Box 743, Arusha, Tanzania \\ Co-authors'emails: remegius.kawala@taec.go.tz (Kawala); alex.muhulo@taec.go.tz (Muhulo); \\ peter.pantaleo@taec.go.tz(Pantaleo); vitus.balobegwa@taec.go.tz (Balobegwa) \\ *Corresponding author: huruma.mammba2@taec.go.tz; peter.huruma2011@gmail.com \\ Received 28 Jan 2021, Revised 27 Apr 2021, Accepted 28 Apr 2021, Published May 2021 \\ DOI: https://dx.doi.org/10.4314/tjs.v47i2.22
}

\begin{abstract}
Natural radionuclides from building materials are one of the potential sources of external as well as internal radiation exposure to the human body. Currently, this exposure has been increasing since people spend more than $80 \%$ of their time indoors (ICRP 1991). Commonly used building materials from Kinondoni District were investigated using $\gamma$-spectrometry; their activity concentrations of ${ }^{226} \mathrm{Ra},{ }^{232} \mathrm{Th}$ and ${ }^{40} \mathrm{~K}$ in $\mathrm{Bg} / \mathrm{kg}$ were measured. The results showed that average values of activity concentrations of ${ }^{226} \mathrm{Ra},{ }^{232} \mathrm{Th}$ and ${ }^{40} \mathrm{~K}$ were $15.62,21.51$ and $237.99 \mathrm{~Bq} / \mathrm{kg}$, respectively. All the activity concentrations in the studied samples were lower than the world average values of $35 \mathrm{~Bq} / \mathrm{kg}$ for ${ }^{226} \mathrm{Ra}, 30 \mathrm{~Bq} / \mathrm{kg}$ for ${ }^{232} \mathrm{Th}$ and $400 \mathrm{~Bq} / \mathrm{kg}$ for ${ }^{40} \mathrm{~K}$. The radium equivalent activity $\left(R a_{e q}\right)$, external $\left(H_{e x}\right)$, internal hazard index $\left(H_{i n}\right)$ and gamma activity concentration index $\left(I_{\gamma}\right)$ were calculated to assess the radiological hazards due to presence of natural radionuclides in the building materials. The results showed that the average values of $\mathrm{Ra}_{\mathrm{eq}}$, $\mathrm{H}_{\mathrm{ex}}$, and $\mathrm{I}_{\gamma}$ were $64.7 \mathrm{~Bq} / \mathrm{kg}, 0.17,0.21$ and 0.24 , respectively. These values were lower than the world criteria values 370 for $\mathrm{Ra}_{\mathrm{eq}}, \leq 1$ for $\mathrm{H}_{\mathrm{ex}}, \leq 1$ for $\mathrm{H}_{\mathrm{in}}$ and $\leq 1$ for $\mathrm{I}_{\gamma}$, respectively. The obtained results indicated that all the investigated building materials were safe for inhabitants.
\end{abstract}

Keywords: Building materials, Natural radionuclides, Radiation hazards, Gamma ray spectrometry, Activity concentration.

\section{Introduction}

Naturally Occurring Radioactive Materials (NORMs) such as potassium-40 and decay series of uranium-238 and thorium-232 are present in most Earth's materials including living species (ARPANSA 2008). Like other radioactive materials, NORMs emit gamma radiations which are generally known as terrestrial background radiations. Moreover, background radiations are the external sources of irradiation of the human body. According to UNSCEAR (2000) report, the exposure resulting from natural radiation sources contributes to average annual effective dose of $2.4 \mathrm{mSv}$. Generally, the activity concentrations of NORMs in most natural substances are low and the levels of exposure to these radionuclides are not significantly to be considered harmful to human health and environment (IAEA 2006, Ismail et al. 2018).

664 
High terrestrial background radiation zones were highly attributed to local geology, geographical positions and geochemical effects (Ab-Samreh et al. 2014). Moreover, human activities such as extraction of minerals from the Earth's crust and refining activities can concentrate radionuclides in soil, water and rocks to levels that are many times higher enough to pose risks to humans and environment (Organo and Fenton 2008, IAEA 2013). Most of building materials are made from the Earth's crust in which the NORMs exist. Therefore, building materials consist of certain amounts of NORMs which are major sources of radiation exposure to humans. Internal and external radiation exposure from NORMs in most building materials have been currently on increase since people spend more than $80 \%$ of their time indoors (ICRP 1991, Brahmanandhan et al. 2007, Estokova and Palascakova 2013, Joela et al. 2018). Prolonged exposure to radionuclides of natural origins above the estimated average dose of $70 \mathrm{nGy} / \mathrm{hr}$ (average indoor absorbed dose rate in air) increases the risks of cancer and possibly cardiovascular diseases (UNSCEAR 1993, Papaefthymiou and Gouseti 2008). To overcome these effects, many studies have been conducted in different regions of the world to determine their activity concentrations of soil, water, rocks and manufactured building materials (Chau et al. 2011, Ding et al. 2013, Asaduzzaman et al. 2016, Joela et al. 2018). For example, a study conducted in Dkaka City in Bangladesh by Asaduzzaman et al. (2016) showed that the activity concentrations of ${ }^{232} \mathrm{Th}$ and ${ }^{40} \mathrm{~K}$ in decorative building materials were higher than the worldwide ranges. Also, Raghu et al (2017) reported highest mean activity concentrations of ${ }^{232} \mathrm{Th}$ in sand samples from Tiruvannamalai District, India. Such data of radioactivity levels obtained at various places are essential for development of guidelines concerning the uses and management of building materials.

Kinondoni is one of the municipals in Dar es Salaam Region with high population. The municipal consists of many local markets and giant industries which produce various building materials for construction in and out of the region (KMC 2018). However, detailed information of activity concentrations of ${ }^{226} \mathrm{Ra}$, ${ }^{232} \mathrm{Th}$ and ${ }^{40} \mathrm{~K}$ in many building materials from the district is not available in the literature. This study intended to assess natural radionuclides from these building materials using $\mathrm{HpGe}$ gamma spectrometry technique. In principle, determination of activity concentrations of radionuclides in this spectrometry technique depends on energy level emitted by radionuclides. The emitted photons from radionuclides are analyzed by HpGe spectroscopy system and the radionuclides are identified and levels are determined.

\section{Materials and Methods \\ Sampling and sample preparation}

The study was carried out at Kinondoni District, Dar es Salaam. The district has population density of 2,896 people per square kilometer. Sand, gravels stones, aggregates, limestone and salt extraction are common mining activities in the district and the products are largely sold to different consumers in large and small quantities (KMC 2018).

In this study, a total of thirty three (33) samples of building materials used for construction in Kinondoni District were collected from local markets, construction sites and licensed mines of sand and clay. All samples with approximately $1 \mathrm{~kg}$ in each were catalogued, dried in temperature-controlled oven at $110 \pm 10{ }^{\circ} \mathrm{C}$ for $48 \mathrm{hr}$ until constant weight was achieved to ensure that moisture was completely removed and organic matter contents were eliminated. Samples were left to cool at room temperature before being crushed into fine powder of particle sizes less than 1 $\mathrm{mm}$. Sieved samples about 400-420 g were filled into labeled canisters to produce the same geometry as the certified reference materials used in this study. The canisters were sealed with adhesive tape to prevent the escape of radiogenic gases. Canisters were then placed in an undisturbed position for a period of 38 days 
in order to attain radioactive secular equilibrium between the $\left({ }^{222} \mathrm{Rn}\right.$ and $\left.{ }^{226} \mathrm{Ra}\right)$ and their progeny. During measurements with gamma ray spectrometry system, the canisters were placed on top of the detector to increase the possibility of gamma ray detection, since the activities of NORMs are normally low.

\section{Measurement of natural radioactivity}

The radionuclide activity concentrations in the prepared building samples were measured using a p-type coaxial high purity germanium (HpGe) detector system. The detector has relative photo peak efficiency of $80 \%$. The detector was maintained in the vertical position in a lead cylindrical shield of $10 \mathrm{~cm}$ thickness. The gamma background level at the counting room was obtained with a clean canister. The background level was obtained under the same conditions of measurement of samples. Spectra were collected for about 12 hours in order to get sufficient net counts at the desired peaks. The spectra were analyzed by Gamma 2000 software. The activity concentrations of ${ }^{226} \mathrm{Ra}$ were determined from its daughters ${ }^{214} \mathrm{Bi}$ at $609.2 \mathrm{keV}$ and ${ }^{214} \mathrm{~Pb}$ at 295.1 and $315.8 \mathrm{keV}$. The activity concentrations of ${ }^{232} \mathrm{Th}$ were obtained by taking ${ }^{228}$ Ac photo peaks at energy of 338.4 and $968.9 \mathrm{keV}$ and ${ }^{212} \mathrm{~Pb}$ photo peak at energy $238.6 \mathrm{keV}$. The activity concentrations of ${ }^{40} \mathrm{~K}$ were determined directly from the photo peak energy of $1461.7 \mathrm{keV}$. Natural radionuclide concentrations of ${ }^{226} \mathrm{Ra},{ }^{232} \mathrm{Th}$ and ${ }^{40} \mathrm{~K}$ were computed by comparing the method using reference materials. The comparisons were achieved using Equation (1) as reported earlier (Abbasi 2013, Ismail et al. 2018).

$$
C_{s}=\frac{M_{s t} A_{s}}{M_{S} A_{s t}} C_{s t}
$$

Where; $\mathrm{C}_{\mathrm{S}}$ is the concentration of radionuclide in the sample $(\mathrm{Bq} / \mathrm{kg}), \mathrm{C}_{\mathrm{st}}$ is the concentration of radionuclide in the standard $(\mathrm{Bq} / \mathrm{kg}), \mathrm{M}_{\mathrm{st}}$ is the mass of the standard sample $(\mathrm{kg}), \mathrm{M}_{\mathrm{S}}$ is the mass of the sample $(\mathrm{kg}), \mathrm{A}_{\mathrm{st}}$ the net area of the standard and $A_{S}$ is the net area of the sample.

\section{Radiological hazards indices \\ Radium equivalent activity $\left(R a_{e q}\right)$}

The radium equivalent activity is a single quantity that is mostly used to account gamma rays emissions from ${ }^{226} \mathrm{Ra},{ }^{232} \mathrm{Th}$ and ${ }^{40} \mathrm{~K}$ (Chau et al. 2011, Abbasi 2013, Joela et al. 2018). As radium and its daughter products produce $98.5 \%$ of the radiological effects of uranium238 decay series, the contribution from the uranium-238 has been replaced with the decay product ${ }^{226} \mathrm{Ra}$ (El-Taher 2012). $\quad \mathrm{Ra}_{\mathrm{eq}}$ is estimated based on the assumption that 370 $\mathrm{Bq} / \mathrm{kg}$ of ${ }^{226} \mathrm{Ra}, 259 \mathrm{~Bq} / \mathrm{kg}$ of ${ }^{232} \mathrm{Th}$ and 4810 $\mathrm{Bq} / \mathrm{kg}$ of ${ }^{40} \mathrm{~K}$ produce the same gamma dose rate (Leonard 2009). The activity values of $\mathrm{Ra}_{\mathrm{eq}}$ are calculated using the Equation (2) as introduced by Beretka and Matthew (1985):

$$
\begin{array}{r}
\mathrm{Ra}_{\mathrm{eq}}=370\left(\frac{A_{R a}}{370}+\frac{A_{T h}}{259}+\frac{A_{K}}{4810}\right) \\
\text { Or, } \mathrm{Ra}_{\mathrm{eq}}=\mathrm{A}_{\mathrm{Ra}}+1.43 \mathrm{~A}_{\mathrm{Th}}+0.077 \mathrm{~A}_{\mathrm{K}}
\end{array}
$$

Where; $A_{\mathrm{Ra}}$ is the activity concentration of ${ }^{226} \mathrm{Ra}$ in $\mathrm{Bq} / \mathrm{kg}, \quad \mathrm{A}_{\mathrm{Th}}$ is the activity concentration of ${ }^{232} \mathrm{Th}$ in $\mathrm{Bq} / \mathrm{kg}$ and $\mathrm{A}_{\mathrm{K}}$ is the activity concentration of ${ }^{40} \mathrm{~K}$ in $\mathrm{Bq} / \mathrm{kg}$. The $\mathrm{Ra}_{\text {eq }}$ value should be less than $370 \mathrm{~Bq} / \mathrm{kg}$ for a building material to be safe by keeping the average annual effective dose within the acceptable limit (< $1 \mathrm{mSv} / \mathrm{yr}$ ) (ICRP 1985, UNSCEAR 2000, IAEA 2018).

\section{External radiation hazard index $\left(H_{e x}\right)$}

$\mathrm{H}_{\mathrm{ex}}$ is another criterion used to estimate the levels of gamma radiation associated with NORMs in different samples of building materials. The external hazard index due to gamma radiation is calculated using criterion Equation (3) (Beretka and Matthew 1985, Sonexay et al. 2018).

$$
\mathrm{H}_{\mathrm{ex}}=\frac{\mathrm{A}_{\mathrm{Ra}}}{370}+\frac{\mathrm{A}_{\mathrm{Th}}}{259}+\frac{\mathrm{A}_{\mathrm{K}}}{4810} \leq 1
$$

Where; $A_{R a}, A_{T h}$ and $A_{K}$ are the specific activity concentrations of ${ }^{226} \mathrm{Ra},{ }^{232} \mathrm{Th}$ and ${ }^{40} \mathrm{~K}$ in $\mathrm{Bq} / \mathrm{kg}$, respectively. The external hazard index is dimensionless quantity which is derived from the expression of the radium 
equivalent activity through the supposition that its maximum permissible value corresponds to the upper limit of $R a_{e q}(370 \mathrm{~Bq} / \mathrm{kg})$. In order to limit the external gamma dose of materials to $1 \mathrm{mGy} / \mathrm{yr}$ for the radiation hazard to be insignificant, the $H_{e x}$ value must be less or equal to one (NEA-OECD 1979, Beretka and Matthew 1985).

\section{Internal radiation hazard index $\left(\mathrm{H}_{\text {in }}\right)$}

The $H_{i n}$ estimates the internal radiation exposure from ${ }^{222} \mathrm{Rn}$ and its daughters that are concentrated in indoor places (Abbasi 2013, Ding et al. 2013, Solomon et al. 2018). The radionuclide ${ }^{222} \mathrm{Rn}$ which is a progeny of ${ }^{226} \mathrm{Ra}$ poses threats to the respiratory organs, when accumulated in large quantity in the indoor air (ICRP 1991). For the safe use of a material in the construction of dwellings, the maximum value of the internal hazard index should be less or equal to one (Brahmanandhan et al. 2007, Asaduzzaman et al. 2016, Amas et al. 2014, Ismail et al. 2018). The internal hazard index is calculated as:

$\mathrm{H}_{\mathrm{in}}=\frac{\mathrm{A}_{\mathrm{Ra}}}{185}+\frac{\mathrm{A}_{\mathrm{Th}}}{259}+\frac{\mathrm{A}_{\mathrm{K}}}{4810} \leq 1$

Where; $A_{\text {Ra }}, A_{T h}$ and $A_{K}$ are the specific activity concentrations of ${ }^{226} \mathrm{Ra},{ }^{232} \mathrm{Th}$ and ${ }^{40} \mathrm{~K}$ in $\mathrm{Bq} / \mathrm{kg}$, respectively.

\section{Gamma activity concentration index $\left(I_{\gamma}\right)$}

$\mathrm{I}_{\gamma}$ is the convenient parameter used to limit the overall contents of radionuclides in concrete and other building materials of mineral origins (EC 1999). Moreover, the index is used to limit the annual external gamma radiation dose from buildings not to exceed $1 \mathrm{mSv} / \mathrm{yr}$ which is the maximum value to the members of the public (ICRP 1985, NCRP 1987). This dose is the excess gamma dose to that received indoors. This index has an advantage of taking into account typical ways and amounts in which the material is used in the building. For the safe use of a building materials, the value of $\mathrm{I}_{\gamma}$ should be less or equal to one for materials used in bulk amounts (such as; cement, gypsum powder, building sand, clay) and less or equal to six for special and other materials with restricted uses (such as tiles, marble, boards) (EC 1999). Equation (5) presents the derived formula of $\mathrm{I}_{\gamma}$ for identifying whether a dose criterion is met:

$$
\mathrm{I}_{\gamma}=\frac{\mathrm{A}_{\mathrm{Ra}}}{300 \mathrm{~Bq} \mathrm{~kg}^{-1}}+\frac{\mathrm{A}_{\mathrm{Th}}}{200 \mathrm{~Bq} \mathrm{~kg}^{-1}}+\frac{\mathrm{A}_{\mathrm{K}}}{3000 \mathrm{~Bq} \mathrm{~kg}^{-1}}
$$

Where; $A_{\mathrm{Ra}}, A_{T h}$ and $A_{K}$ are the activity concentrations $(\mathrm{Bq} / \mathrm{kg})$ of ${ }^{226} \mathrm{Ra},{ }^{232} \mathrm{Th}$ and ${ }^{40} \mathrm{~K}$, respectively.

\section{Results and Discussion \\ Activity concentrations}

The average activity concentrations of ${ }^{226} \mathrm{Ra},{ }^{232} \mathrm{Th}$ and ${ }^{40} \mathrm{~K}$ together with their minimum and maximum activity concentrations of the building materials are presented in Table 1. The results showed that the activity concentrations of ${ }^{226} \mathrm{Ra},{ }^{232} \mathrm{Th}$ and ${ }^{40} \mathrm{~K}$ varied from $3.3 \pm 0.5$ (gypsum powder) to $39.1 \pm 0.6 \mathrm{~Bq} / \mathrm{kg}$ (marble stone), 0.2 (gypsum powder) to $54.1 \pm 1.2 \mathrm{~Bq} / \mathrm{kg}$ (marble stone) and 0.3 (gypsum powder) to $725.4 \pm 8.3 \mathrm{~Bq} / \mathrm{kg}$ (clay), respectively. The average values of activity concentrations of ${ }^{226} \mathrm{Ra},{ }^{232} \mathrm{Th}$ and ${ }^{40} \mathrm{~K}$ were 15.62, 21.51 and $237.99 \mathrm{~Bq} / \mathrm{kg}$, respectively. These results of average values of ${ }^{226} \mathrm{Ra},{ }^{232} \mathrm{Th}$ and ${ }^{40} \mathrm{~K}$ were lower than the worldwide average values as reported by UNSCEAR (1993) which were 35, 30 and 400 $\mathrm{Bq} / \mathrm{kg}$, respectively. In order to observe variations of radionuclides concentrations of the studied samples, average activity concentrations of ${ }^{226} \mathrm{Ra},{ }^{232} \mathrm{Th}$ and ${ }^{40} \mathrm{~K}$ were plotted against the building materials (Figure 1). As can be seen from Figure 1, the activity concentrations of ${ }^{40} \mathrm{~K}$ were higher than that of ${ }^{226} \mathrm{Ra}$ and ${ }^{232} \mathrm{Th}$. This noticeable difference could be due to its abundance in the Earth's crust from which majority of the construction raw materials are extracted.

For comparison purposes, the average concentrations of ${ }^{226} \mathrm{Ra},{ }^{232} \mathrm{Th}$ and ${ }^{40} \mathrm{~K}$ radionuclides from several countries in the world are presented in Table 2. As shown from the table, the radioactivity in building materials varied from one place to other. However, it was 
found out that the average concentrations values of ${ }^{226} \mathrm{Ra},{ }^{232} \mathrm{Th}$ and ${ }^{40} \mathrm{~K}$ radionuclides in this study were much lower than many places in the world. In addition to that, the obtained values of activity concentrations of ${ }^{226} \mathrm{Ra},{ }^{232} \mathrm{Th}$ and ${ }^{40} \mathrm{~K}$ for cement samples from this study were similarly reported in a previous study conducted in Dar es Salaam, Mbeya and Tanga regions, Tanzania (Amas et al. 2014). It is noted that no data is currently available on marble, gypsum powder, building sand and clay in Tanzania for comparison.

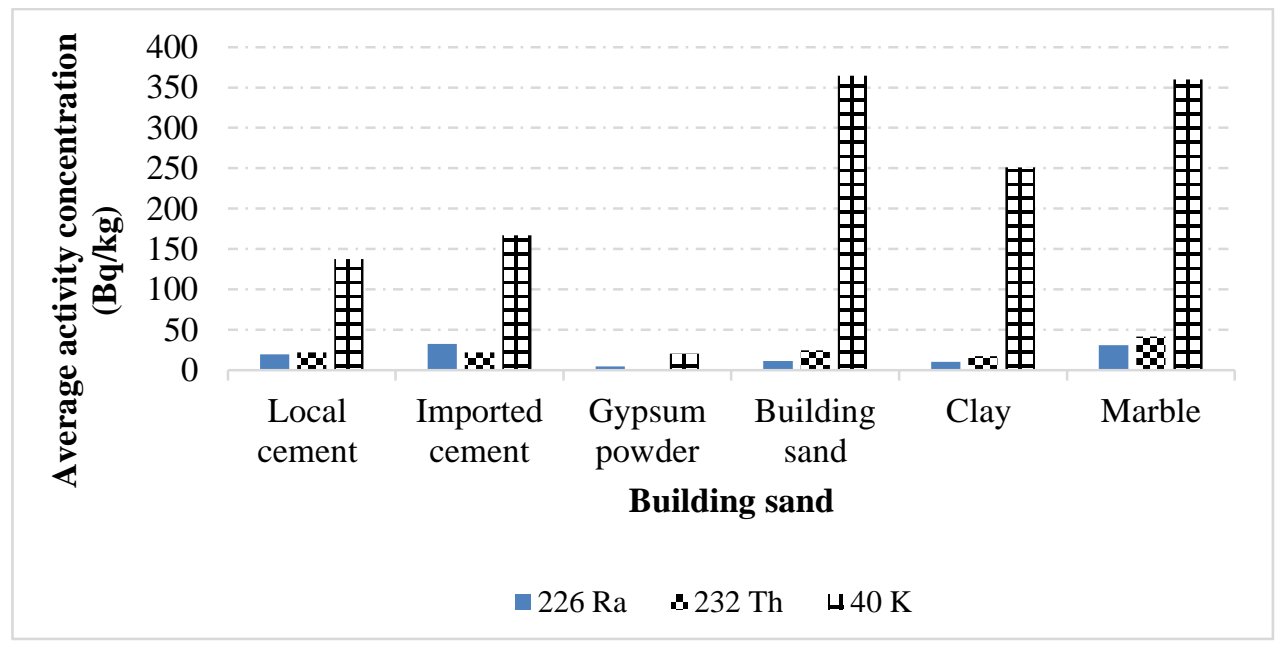

Figure 1: Activity concentrations of ${ }^{226} \mathrm{Ra},{ }^{232} \mathrm{Th}$ and ${ }^{40} \mathrm{~K}$ in $\mathrm{Bq} / \mathrm{kg}$ for the selected building materials used in Kinondoni District.

\section{Assessment of the radiological hazards}

In this study, common radiation hazard indices called the radium equivalent activity $\left(\mathrm{Ra}_{\mathrm{eq}}\right)$, external $\left(\mathrm{H}_{\mathrm{ex}}\right)$ and internal radiation hazard index $\left(\mathrm{H}_{\text {in }}\right)$ and gamma activity concentration index $\left(\mathrm{I}_{\gamma}\right)$ were calculated using the results of the activity concentrations. The obtained values of indices were used to estimate the risks of radiation exposure from building materials used in Kinondoni District. The calculated data for $\mathrm{Ra}_{\mathrm{eq}}, \mathrm{H}_{\mathrm{in}}, \mathrm{H}_{\mathrm{ex}}$ and $\mathrm{I} \gamma$ of the collected building samples are presented in Table 3

\section{Radium equivalent activity ( $\left.R a_{e q}\right)$}

As can be observed from Table 3, the calculated values of $\mathrm{Ra}_{\mathrm{eq}}$ were found to vary from $5.51 \mathrm{~Bq} / \mathrm{kg}$ (gypsum powder) to 161.91 $\mathrm{Bq} / \mathrm{kg}$ (building sand), with an average value of 64.7 Bq/kg. These values are lower than recommended criterion limit of $370 \mathrm{~Bq} / \mathrm{kg}$. All materials examined in this study are acceptable for the uses as building materials as defined by UNSCEAR (2000).

\section{External radiation hazard index $\left(\mathrm{H}_{e x}\right)$}

The calculated values of $\mathrm{H}_{\mathrm{ex}}$ for all the studied samples are presented in column six, seven and eight of Table 3 . It is observed that the $\mathrm{H}_{\mathrm{ex}}$ values ranged from 0.01 (gypsum powder) to 0.46 (building sand) with an average value of $\mathrm{H}_{\text {ex }}$ found to be 0.17 . Since these values are within the recommended criterion limit $\left(\mathrm{H}_{\mathrm{ex}}<1\right)$, we can say that the radiation hazards are insignificant for the population living in the investigated area. 
Tanz. J. Sci. Vol. 47(2), 2021

\begin{tabular}{|c|c|c|c|c|c|c|c|c|c|c|}
\hline \multirow{2}{*}{ Sample type } & \multirow{2}{*}{$\begin{array}{c}\text { No. of } \\
\text { samples }\end{array}$} & \multicolumn{3}{|l|}{${ }^{226} \mathbf{R a}$} & \multicolumn{3}{|l|}{${ }^{232} \mathrm{Th}$} & \multicolumn{3}{|l|}{${ }^{40} \mathrm{~K}$} \\
\hline & & Min. & Max. & Avg. & Min. & Max. & Avg. & Min. & Max. & Avg. \\
\hline Local cement & 5 & $16.7 \pm 0.8$ & $26.3 \pm 0.6$ & 19.64 & $15.0 \pm 1.6$ & $36.3 \pm 1.5$ & 22.2 & $95.6 \pm 5.7$ & $269.9 \pm 6.0$ & 137.66 \\
\hline Imported cement & 2 & $28.2 \pm 0.7$ & $36.1 \pm 0.6$ & 32.5 & $3.4 \pm 1.2$ & $41.0 \pm 1.8$ & 22.2 & $48.3 \pm 3.9$ & $286.4 \pm 7.4$ & 167.35 \\
\hline Gypsum powder & 5 & $3.3 \pm 0.5$ & $5.4 \pm 0.5$ & 4.4 & 0.2 & $4.8 \pm 0.2$ & 1.56 & 0.3 & $50.6 \pm 0.5$ & 20.64 \\
\hline Building sand & 8 & $7.7 \pm 0.5$ & $25.9 \pm 0.9$ & 11.28 & $12.9 \pm 1.6$ & $76.3 \pm 2.3$ & 24.55 & $298.7 \pm 5.1$ & $598.8 \pm 5.4$ & 364.64 \\
\hline Clay & 8 & $6.5 \pm 0.5$ & $12.3 \pm 0.7$ & 10.3 & $11.9 \pm 1.5$ & $21.8 \pm 0.8$ & 17.6 & $83.5 \pm 5.8$ & $725.4 \pm 8.3$ & 251.18 \\
\hline Marble & 5 & $21.6 \pm 0.8$ & $39.1 \pm 0.6$ & 31.0 & $31.5 \pm 1.8$ & $54.1 \pm 1.2$ & 41.86 & $196.5 \pm 7.7$ & $621.1 \pm 6.3$ & 360 \\
\hline Total & 33 & $3.3 \pm 0.5$ & $39.1 \pm 0.6$ & 15.62 & 0.2 & $76.3 \pm 2.3$ & 21.51 & 0.3 & $725.4 \pm 8.3$ & 237.99 \\
\hline
\end{tabular}

Table 2: The average activity concentrations of ${ }^{226} \mathrm{Ra},{ }^{232} \mathrm{Th}$ and ${ }^{40} \mathrm{~K}$ in Bq/kg of building materials from several countries in the world

\begin{tabular}{|c|c|c|c|c|c|}
\hline Location and Country & Sample type & ${ }^{226} \mathrm{Ra}$ & ${ }^{232} \mathrm{Th}$ & ${ }^{40} \mathrm{~K}$ & Source/Reference \\
\hline \multirow[t]{2}{*}{ Tehran, Iran } & Granite stones & $76 \pm 9$ & $72 \pm 2$ & $1193 \pm 23$ & \multirow[t]{2}{*}{ Abbasi (2013) } \\
\hline & Cement & $37.76 \pm 3.16$ & $13.77 \pm 1.04$ & $116.07 \pm 7.34$ & \\
\hline \multirow[t]{2}{*}{ Thoulakhom, Laos } & Sand & $17.08 \pm 1.12$ & $23.14 \pm 0.72$ & $463.31 \pm 12.28$ & \multirow[t]{2}{*}{ Sonexay et al. (2018) } \\
\hline & Soil & $22.81 \pm 1.22$ & $27.22 \pm 0.86$ & $235.49 \pm 7.51$ & \\
\hline Tiruvanamalai \& Tamirnadu, India & Sand & 119.42 & 388.78 & 388.78 & Raghu et al. (2017) \\
\hline Najaf Governorate, Iraq & Soil & - & 6.68 & 277.5 & Hussain and Hussain (2011) \\
\hline \multirow[t]{2}{*}{ Mirpur Azad Kashmir, Pakistan } & Soil & $27.4 \pm 8.4$ & 52.13 & $478 \pm 111$ & \multirow[t]{2}{*}{ Rafique et al. (2011) } \\
\hline & Clay & $53.6 \pm 3.4$ & $58.5 \pm 3.2$ & $748 \pm 17$ & \\
\hline \multirow[t]{2}{*}{ Estonia } & Gypsum board & $4.4 \pm 1.0$ & $0.8 \pm 0.2$ & $7.0 \pm 0.4$ & \multirow[t]{2}{*}{ Lust and Realo (2012) } \\
\hline & Kunda cement & $46.9 \pm 2.8$ & $21.4 \pm 1.6$ & $587 \pm 13$ & \\
\hline \multirow[t]{3}{*}{ Slovack Republic } & Cement & 19.1 & 26.3 & 489.4 & \multirow[t]{3}{*}{ Estokova and Palaskakova (2013) } \\
\hline & Sand & 12.3 & 19.7 & 260 & \\
\hline & Gravels & 14.7 & 24.2 & 195 & \\
\hline \multirow[t]{4}{*}{ Qassim, Saudi Arabia } & Limestone & 28.6 & 49.2 & 66 & \multirow[t]{4}{*}{ El-Taher (2012) } \\
\hline & Gypsum & 33.28 & 47.2 & 88 & \\
\hline & Cement & 38.4 & 45.3 & 86 & \\
\hline & Cement & 60.5 & 64.7 & 952.2 & \\
\hline \multirow{3}{*}{ Dhaka, Bangladesh } & Gypsum & 58.4 & 91.2 & 1101 & \multirow{3}{*}{ Assaduzzaman et al. (2014) } \\
\hline & Brick & 57.5 & 75.8 & 1080 & \\
\hline & Sand & 49.1 & 71.6 & 927.2 & \\
\hline Tanzania & Cement & 46 & 28 & 228 & Amas et al. (2014) \\
\hline Dahomey & Soil & 16.4 & 12 & 215.4 & Otoo et al. (2012) \\
\hline
\end{tabular}


Mammba - Assessment of natural radioactivity and radiation hazards of building materials ...

Table 3: The radium equivalent activity $\left(\mathrm{Ra}_{\mathrm{eq}}\right)$, external $\left(\mathrm{H}_{\mathrm{ex}}\right)$ and internal radiation hazard index $\left(\mathrm{H}_{\mathrm{in}}\right)$, and gamma activity concentration index $\left(\mathrm{I}_{\gamma}\right)$ of samples of building materials collected from Kinondoni District, Dar es Salaam

\begin{tabular}{|c|c|c|c|c|c|c|c|c|c|c|c|c|c|}
\hline \multirow{2}{*}{ Sample type } & \multirow{2}{*}{$\begin{array}{l}\text { No of } \\
\text { samples }\end{array}$} & \multicolumn{3}{|c|}{ Req in $\mathrm{Bq} / \mathbf{k g}$} & \multicolumn{3}{|l|}{ Hex } & \multicolumn{2}{|l|}{ Hin } & \multicolumn{3}{|c|}{$\mathbf{I} \gamma$} & \multirow[b]{2}{*}{ Avg. } \\
\hline & & Min. & Max. & Avg. & Min. & Max. & Avg. & Min. & Max. & Avg. & Min. & Max. & \\
\hline Local cement & 5 & 46.07 & 98.99 & 61.98 & 0.12 & 0.27 & 0.17 & 0.17 & 0.3 & 0.22 & 0.17 & 0.36 & 0.22 \\
\hline Imported cement & 2 & 44.68 & 108.88 & 78.78 & 0.12 & 0.29 & 0.21 & 0.22 & 0.37 & 0.29 & 0.38 & 0.39 & 0.39 \\
\hline Gypsum powder & 5 & 5.51 & 40.18 & 8.22 & 0.01 & 0.03 & 0.02 & 0.03 & 0.04 & 0.03 & 0.02 & 0.04 & 0.03 \\
\hline Building sand & 8 & 33.07 & 161.91 & 74.46 & 0.09 & 0.44 & 0.2 & 0.12 & 0.51 & 0.23 & 0.12 & 0.58 & 0.28 \\
\hline Clay & 8 & 35.62 & 98.34 & 54.64 & 0.09 & 0.27 & 0.15 & 0.11 & 0.29 & 0.17 & 0.13 & 0.24 & 0.21 \\
\hline Marble & 5 & 83.55 & 164.29 & 118.59 & 0.23 & 0.44 & 0.32 & 0.28 & 0.55 & 0.4 & 0.3 & 0.61 & 0.43 \\
\hline Total & 33 & 5.51 & 161.9 & 64.7 & 0.01 & 0.44 & 0.17 & 0.03 & 0.55 & 0.21 & 0.02 & 0.61 & 0.24 \\
\hline
\end{tabular}




\section{Internal radiation hazard index $\left(\boldsymbol{H}_{\text {in }}\right)$}

The calculated data for $\mathrm{H}_{\text {in }}$ of the collected building samples are presented in column nine, ten and eleven of Table 3. From these results, $\mathrm{H}_{\mathrm{in}}$ values ranged from 0.03 (gypsum powder) to 0.55 (marble stone), with an average value of 0.21 all values were below the criterion value of $(\leq 1)$, indicating that the materials are free from internal radiation hazards (Brahmanandhanet al. 2007, Asaduzzaman et al. 2016, Amas et al. 2014, Ismail et al. 2018).

\section{Gamma activity concentration index $\left(I_{\gamma}\right)$}

As can be observed from Table 3, the calculated values of $I_{\gamma}$ were found to vary from 0.02 (gypsum powder) to 0.61 (marble), with an average value of 0.24 . In all the building samples, the calculated values of $\mathrm{I}_{\gamma}$ were found to be lower than 1, corresponding to an annual effective dose of generally less than $1 \mathrm{mSv} / \mathrm{yr}$ (ICRP 1985, NCRP 1987).

\section{Conclusions}

The present study was conducted to establish baseline data regarding levels of natural radionuclides concentrations of ${ }^{226} \mathrm{Ra},{ }^{232} \mathrm{Th}$ and ${ }^{40} \mathrm{~K}$ in commonly used building materials from Kinondoni District using $\gamma$ spectrometry technique. The results of this study showed the activity concentrations of ${ }^{226} \mathrm{Ra},{ }^{232} \mathrm{Th}$ and ${ }^{40} \mathrm{~K}$ in all the samples were in the range of limit values. Furthermore, it was observed that the values of radionuclides concentration obtained in current study were slightly lower compared with the results from similar studies carried out in some other parts of the world.

The estimated values of radiation hazard parameters which included external hazard index, internal hazard index and gamma activity concentration index were within their recommended safety limits. Therefore, the uses of these building materials in construction do not pose any significant radiation hazards, and hence the materials can be considered to be safe for the inhabitants. However, it is recommended that further assessments on the levels of natural radionuclides and radon for other types of building materials should be determined to ensure the safety of dwellers in the district.

The data generated in this study can be used as a reference for more extensive studies of the same subject matter in other districts. Furthermore, the policy makers should consider risks associated with radionuclides of natural origins from local and imported building materials and impose strict measures that will practically govern the use of those materials.

\section{Acknowledgement}

We are thankful to Tanzania Atomic Energy Commission for providing funds and research facilities.

\section{References}

Abbasi A 2013 Environmental radiation in high exposure building materials. $\mathrm{PhD}$ thesis, Eastern Mediterranean University.

Ab-Samreh MM, Thabayneh KM and Khrais FW 2014 Measurement of activity concentration levels of radionuclides in soil samples collected from Bethlehem province, West Bank, Palestine. Turkish J. Eng. Env. Sci. 38: 113-125.

Amas AI, Mtei KM, Nathan IJ, Jodlowski P and Dinh CN 2014 Natural radioactivity in Tanzania cements and their raw materials. Res. J. Environ. Earth Sci. 6(10): 469-474.

ARPANSA (Australian Radiation Protection and Nuclear Safety Agency) 2008 Management of naturally occurring radioactive material (NORM). Radiation Protection Series Number, 15. Victoria.

Asaduzzaman KH, Khandaker MU, Amin YM and Bradley DA 2016 Natural radioactivity levels and radiological assessment of decorative building materials in Bangladeshi. Indoor and Built Environ. 25(3): 541-550.

Beretka J and Matthew PJ 1985 Natural radioactivity of Australian building materials, industrial wastes and byproducts. Health Phys. 48: 87-95.

Brahmanandhan GM, Malathi J, Khanna D, Selvasekarapandian S, Nidhya N, Usharani 
R, Jose MT and Meenakshisundaram V 2007 Natural radioactivity and indoor radiation measurements in buildings and building materials in Gobichettipalayam town. J. Radioanal. Nucl. Chem. 274(2): 373-377.

Chau DN, Dulinski M, Jodlwski P, Nowak J, Rozanski K, Sleziak $M$ and Wachniew 2011 Natural radioactivity in ground watera review. Isotop. Environ. Health Stud. 47: 415-437.

Ding X, Lu X, Zhao C, Yang G and Li N 2013 Measurement of natural radioactivity in building materials used in Urumqi, China. Radiat. Pro. Dosim. 155(3): 374-379.

EC (European Commission) 1999 Radiological protection principles concerning the natural radioactivity of building materials. Radiation protection report 112 . Geneva.

El-Taher A 2012 Assessment of natural radioactivity levels and associated radiation hazards for building materials used in Qassim area, Saudi Arabia. Rom. J. Phys. 57: 726-735.

Estokova A and Palascakova L 2013 Assessment of natural radioactivity levels of cements and cement composites in the Slovak Republic. Int. J. Environ. Res. Public Health 10: 7165-7179.

Hussain RO and Hussain HH 2011 Natural occurring radionuclide materials. In: Singh $\mathrm{N}$ (ed) Radioisotopes-applications in physical science (pp. 3 -20), Intech, Rijeka.

IAEA (International Atomic Energy Agency) 2006 Regulatory and management approaches for the control of environmental residues containing naturally occurring radioactive material (NORM), Proceedings of a technical meeting held in Vienna, 6-10 December 2004. IAEA-TECDOC-1484. Vienna.

IAEA (International Atomic Energy Agency) 2013 Management of NORM residue. International Atomic Energy Agency. Vienna.

IAEA (International Atomic Energy Agency) 2018 International Atomic Energy Agency, Radiation Protection of the Public and the
Environment, IAEA safety standards series No. GSG-8. Vienna.

ICRP (International Commission on Radiological Protection) 1985 Statement from the 1985 Paris meeting of the international commission on radiological protection. ICRP Publication 60. ICRP. Paris.

ICRP (International Commission on Radiological Protection) $1991 \quad 1990$ Recommendations of the International Commission on Radiological Protection. Pergamos Press. London.

Ismail AF, Abdullahi S, Samat S and Yasir MS 2018 Radiological dose assessment of natural radioactivity in Malaysian tiles using resrad-build computer code. Sains Malaysiana 47(5): 1017-1023.

Joel ES, Maxwell O, Adewoyin OO, EhiEromosele CO, Embong $\mathrm{Z}$ and Oyawoye F 2018 Assessment of natural radioactivity in various commercial tiles used for building purposes in Nigeria. MethodsX 5: 8-19.

KMC (Kinondoni Municipal Council) 2018 Municipal profile 2018, Kinondoni Municipal Council. Dar es Salaam.

Leonard C 2009 Natural radioactivity hazards of building bricks fabricated from clay soil of Bomet district, Bomet County, Kenya. MSc Thesis, School of Pure and Applied Sciences of Kenyatta University.

Lust M and Realo E 2012 Assessment of natural radiation exposure from building materials in Estonia. Proc. Estonia Acad. Sci. 61(2): 107-112.

NCRP (National Council on Radiation Protection and Measurement) 1987 Exposure of the population in United States and Canada from natural background radiation. Supersedes NCRP Report No 45. (Bethesda MD200814). West Virginia.

NEA-OECD (Nuclear Energy Agency) 1979 Exposure to radiation from Natural radioactivity in building materials. NEA group of expert report. Paris.

Organo C and Fenton D 2008 Radiological assessment of NORM industries in Irelandradiation doses to workers and members of 
the public. Radiological Protection Institute of Ireland. Dublin.

Otoo F, Darko EO, Emi-Reynolds GM, Andam AB and Adukpo OK 2012 Radiological impact of soil as a source of building materials. Radiat. Protect. Environ. 35(1): 22-29.

Papaefthymiou H and Gouseti O 2008 Naturally radioactivity and associated radiation hazards in building materials used in Pelopannese, Greece. Radiat. Measure. 43: 1453-1457.

Rafique M, Rehman H, Matiullah, Malik F, Rajput MU, Rahman SU and Rathore MH 2011 Assessment of radiological hazards due to soil and building materials used in Mirpur Azad Kashmir. Iran. J. Radiat. Res. 9(2): 77-87.

Raghu Y, Chandrasekaran A, Selvapandiyan M, Harikrishnan N and Ravisankar R 2017 Natural radioactivity measurement and radiological hazards of sand samples used as building materials in Tiruvannamalai district, Tamilnadu, India. Int. J. Mater. Sci. 12: $335-344$
Solomon AO, Chagok NM, Ashano EC, Ogunleye PO, Otebe $\mathrm{S}$ and Rimven BN 2018 Indoor gamma ray measurement of residential mud buildings in Miango, North Central Nigeria. J. Nat. Sci. Res. 8(6): 91100.

Sonexay X, Khiem LM and Nam LD 2018 Assessment of natural radioactivity levels and radiation hazards of building materials of Lao PDR. Int. J. Mod. Eng. Res. 8(4): 29-35.

UNSCEAR (United Nations Scientific Committee on the Effects of Atomic Radiation) 1993 United Nations Scientific Committee on the Effects and Atomic Radiation: sources, Effects and Rises the General Assembly, United Nations. New York.

UNSCEAR (United Nations Scientific Committee on the Effects of Atomic Radiation) 2000 Sources and Effects of Ionizing Radiation. United Nations Vol.1, United Nations Publication. New York. 